\title{
Penentuan Spesies dan Uji Efektivitas Bacillus Thuringiensis Israelensis H-14 Terhadap Larva Nyamuk Anopheles spp Sebagai Vektor Malaria di Kecamatan Sikakap Kabupaten Kepulauan Mentawai
}

\author{
Yoseph De Nachs ${ }^{1}$, Hasmiwati², Selfi Renita Rusjdi ${ }^{3}$
}

\begin{abstract}
Abstrak
Nyamuk Anopheles spp adalah vektor utama penyebab penyakit malaria. Pengendalian vektor malaria dapat dilakukan dengan bioinsektisida salah satunya menggunakan Bacillus thuringiensis israelensis $\mathrm{H}-14$. Tujuan penelitian ini adalah untuk mengidentifikasi spesies Anopheles dan mengetahui efektivitas Bacillus thuringiensis israelensis $\mathrm{H}-14$ terhadap larva nyamuk Anopheles di Kecamatan Sikakap Kabupaten Kepulauan Mentawai. Penelitian ini bersifat deskriptif dan eksperimental yang dilaksanakan pada Juli 2017 - Maret 2018. Teknik pengambilan sampel dalam penelitian ini adalah konsekutif sampling berupa larva instar III dari Kecamatan Sikakap Kabupaten Kepulauan Mentawai. Larva yang didapatkan dilapangan diidentifikasi untuk menentukan spesies dan selanjutnya dilakukan uji efektivitas dengan 5 konsentrasi yaitu 0.0025, 0.005, 0.01, 0.02 dan $0.04 \%$ serta ditambah dengan kontrol. Hasil penelitian didapatkan spesies Anopheles yang terbanyak di Kecamatan Sikakap Kabupaten Kepulauan Mentawai adalah Anopheles subpictus. Nilai LC50 didapatkan pada konsentasi $0.005 \%$ dan LC90 terdapat pada konsentrasi $0.015 \%$ setelah 48 jam perlakuan. Penghitungan dengan konsentrasi $0.04 \%$ didapatkan kematian larva LT50 dicapai pada menit ke 1123.30 dan LT90 pada menit ke 1682.25. Kesimpulannya adalah spesies Anopheles yang terbanyak di Kecamatan Sikakap Kabupaten Kepulauan Mentawai adalah Anopheles subpictus dan Bacillus thuringiensis israelensis $\mathrm{H}-14$ efektif menyebabkan kematian larva instar III nyamuk Anopheles dengan konsentrasi yang rendah.
\end{abstract}

Kata kunci: Bacillus thuringiensis israelensis, Anopheles spp, Anopheles subpictus, LC50, LC90, LT50, LT90.

\section{Abstract}

Anopheles spp mosquitoes are the main vector for malaria disease. Control of malaria vector could be done with bioinsecticide, one of them using Bacillus thuringiensis israelensis $\mathrm{H}-14$. This research aimed to identify the Anopheles species and to know the effectiveness of Bacillus thuringiensis israelensis $\mathrm{H}-14$ against Anopheles mosquito larvae in Sikakap district of Mentawai archipelago regency. This study was descriptive and experimental design conducted on July 2017 - March 2018. Sample collected was instar III larvae from Sikakap district of Mentawai archipelago regency by using consecutive sampling. The species of larvae collected would be identified and tested for the effectiveness within 5 concentrations of $0.0025,0.005,0.01,0.02$, and $0.04 \%$ and compared with control sample. The result showed that Anopheles species mostly found in Sikakap district of Mentawai archipelago regency was Anopheles subpictus. LC50 score on $0.005 \%$ of concentration and LC90 on $0.015 \%$ of concentration after 48 hours of intervention. Counting on $0.04 \%$ concentration found that LT50 larvae death was achieved in 1123.30 minute and LT90 larvae death on 1682.25 minute. The conclusion of this reseach is that Anopheles species mostly found in Sikakap district of Mentawai archipelago regency was Anopheles subpictus and Bacillus thuringiensis israelensis $H-14$ was effective against Anopheles larvae instar III by low concentration.

Keywords: Bacillus thuringiensis israelensis, Anopheles spp, Anopheles subpictus, LC50, LC90, LT50, LT90. 
Affiliasi penulis : 1. Profesi Dokter FK UNAND (Fakultas Kedokteran Universitas Andalas Padang), 2. Bagian Parasitologi FK UNAND,

3. Bagian Parasitologi FK UNAND

Korespondensi : Yoseph De Nachs, email:

yosephdenachss@gmail.com Telp: 082172820513

\section{PENDAHULUAN}

Malaria adalah penyakit yang disebabkan oleh parasit yang ditularkan melalui gigitan nyamuk Anopheles yang terinfeksi oleh plasmodium. Plasmodium yang menginfeksi manusia yaitu Plasmodium falciparum, Plasmodium vivax, Plasmodium malariae, dan Plasmodium ovale. Malaria merupakan penyakit reemerging atau menular kembali secara massal dan merupakan salah satu penyakit yang sangat berbahaya. Gejala yang sering di temukan pada penderita malaria antara lain demam yang hilang timbul, menggigil, berkeringat, sakit otot, anemia, mual, muntah dan adanya pembesaran limpa. ${ }^{1}$

World Health Organization (WHO) pada tahun 2015 menyatakan bahwa malaria menyerang 106 negara di dunia, diantaranya Afrika, Brazil, Amerika Tengah, Amerika Latin, Haiti, Asia Selatan, Asia Tenggara, serta negara lainnya. Dalam dekade terakhir ini upaya pengendalian vektor penyebab malaria sangat gencar dilakukan sehingga menyebabkan penurunan yang sangat dramatis. ${ }^{2}$ Secara global diperkirakan ada 429.000 kematian akibat malaria pada tahun 2015. Sebagian besar kematian terjadi di wilayah Afrika (92\%), diikuti dengan wilayah Asia Tenggara (6\%) dan wilayah Timur Mediterania (2\%). Penyebab kematian 99\% disebabkan oleh Plasmodium falciparum. ${ }^{3}$

Berdasarkan Data dan Informasi Profil Kesehatan Indonesia tahun 2016 menunjukkan bahwa Annual Parasite Insidence (API) malaria adalah 0,77 per 1000 penduduk. Angka klinis malaria di Sumatera Barat mengalami penurunan dari tahun ke tahun yaitu 0,10 pada tahun 2016. ${ }^{4}$ Profil Kesehatan Sumatera Barat tahun 2016 menunjukkan bahwa Kabupaten dengan API malaria tertinggi di Sumatera Barat berada di Kabupaten Kepulauan Mentawai yaitu sebesar 4,00 per 1.000 penduduk. $^{5}$

Nyamuk Anopheles merupakan vektor utama yang menularkan malaria di dunia. Anopheles gambiae merupakan vektor utama malaria di Afrika, sedangkan di Amerika utara adalah Anopheles freeborni. Spesies nyamuk yang menjadi vektor malaria di India lebih banyak di bandingkan negara lain, yaitu ada sekitar 45 spesies, antara lain Anopheles culifacies, Anopheles fluviatilis, Anopheles sundaicus, Anopheles stephensis dan banyak lainnya tergantung daerah sebaran nyamuk tersebut. Sementara di Indonesia ada sekitar 20 spesies yang menjadi vektor utama penular malaria, seperti Anopheles aconitus, Anopheles sundaicus, Anopheles subpictus, Anopheles maculatus, dan lain sebagainya. ${ }^{6}$

Jenis nyamuk Anopheles yang ada di daerah endemis malaria di Kabupaten Kepulauan Mentawai belum diketahui spesiesnya. Berdasarkan zona tempat perindukan nyamuk Anopheles yaitu salah satunya zona pantai, maka Anopheles sundaicus dan Anopheles subpictus yang dicurigai menjadi vektor utama penyakit malaria di Kecamatan Sikakap Kabupaten Kepulauan Mentawai. Hutan bakau dan air payau serta sungai-sungai kecil merupakan habitat nyamuk penular malaria yang ada di Kecamatan Sikakap Kabupaten Kepulauan Mentawai.

Penggunaan insektisida kimia diduga menyebabkan resistensi terhadap vektor, maka dikembangkan pengendalian vektor dengan pemanfaatan bioinsektisida baik yang berasal dari tumbuhan (nabati) ataupun dengan pemanfaatan bakteri penyebab penyakit pada serangga seperti Bacillus sphaericus dan Bacillus thuringiensis. Penggunaan Bacillus thuringiensis sebagai insektisida sudah dikembangkan secara luas, baik dibidang kesehatan yaitu Bacillus thuringiensis israelensis maupun dibidang pertanian yaitu pemanfaatan Bacillus thuringiensis kurstaki untuk pengendalian hama ulat jagung. ${ }^{7}$

Pengendalian vektor malaria menggunakan Bacillus thuringiensis juga sudah sangat berkembang dan telah dilakukan terhadap beberapa spesies Anopheles. Pengendalian vektor menggunakan Bacillus thuringiensis sangat efektif untuk menekan jumlah verktor malaria karena tidak bersifat toksik terhadap organisme non-target. ${ }^{8}$ Penggunaan Bacillus spp efektif untuk membunuh jentik nyamuk Anopheles spp dan telah diteliti di Indonesia. Pengujian terhadap Anopheles barbirostris menunjukkan formulasi liquid larvasida Bacillus sphaericus mampu membunuh $90 \%$ jentik dalam 24 jam pada dosis 2 ppm. ${ }^{9}$ Bacillus thuringiensis israelensis telah digunakan selama puluhan tahun di beberapa negara dan sampai saat ini 
belum ada laporan mengenai resistensi vektor malaria terhadap Bacillus thuringiensis israelensis. ${ }^{10}$

\section{METODE}

Penelitian ini bersifat deskriptif dan eksperimental. Pengambilan sampel penelitian ini dilaksanakan di Kecamatan Sikakap Kabupaten Kepulauan Mentawai. Identifikasi, pemeliharaan dan pengujian sampel dilakukan di Laboratorium Parasitologi Universitas Andalas. Penelitian ini dimulai dari bulan Juli 2017 sampai dengan Maret 2018.

Populasi pada penelitian ini adalah larva nyamuk Anopheles spp di Kecamatan Sikakap Kabupaten Kepulauan Mentawai yang merupakan daerah endemis malaria hingga saat ini.

Sampel dalam penelitian adalah larva Anopheles spp yang memenuhi kriteria inklusi dan tidak termasuk dalam kriteria eksklusi. Sampel dari penelitian ini diambil sebanyak-banyaknya dari tempat pengambilan larva nyamuk Anopheles spp di Kecamatan Sikakap Kabupaten Kepulauan Mentawai. Berdasarkan standar WHO tahun 2016, besar sampel dalam satuan pengamatan adalah sebanyak 20-25 ekor larva Anopheles spp.

Teknik pengambilan sampel dalam penelitian ini adalah Consecutive sampling. Consecutive sampling yaitu pemilihan sample dengan menetapkan subjek yang memenuhi kriteria penelitian dimasukkan dalam penelitian sampai kurun waktu tertentu, sehingga jumlah sampel dapat terpenuhi.

Teknik analisis yang digunakan adalah:

1. Penghitungan persentase kematian larva Penghitungan persentase kematian larva dihitung menggunakan rumus:

$\%$ kematian $=\underline{\text { Larva mati pada waktu tertentu }} \times 100 \%$ Jumlah larva awal

\section{Analisis Probit}

Analisis probit dimaksudkan untuk mengetahui dan menentukan LT50 dan LT90 serta LC50 dan LC90 dari Bacillus thuringiensis israelensis terhadap larva nyamuk Anopheles.

HASIL

Penelitian ini dilakukan pada Juli 2017 - Maret
Anopheles. Penelitian dilakukan dengan mengamati serta mencatat keberadaan larva dari semua tempat perindukan yang terdapat di Kecamatan Sikakap Kabupaten Kepulauan Mentawai dan mengambil semua larva nyamuk yang ditemukan.

\section{Penentuan Spesies}

Identifikasi dilakukan secara makroskopis dan mikroskopis. Identifikasi secara makroskopis dilakukan dengan pengamatan menggunakan mata telanjang. Ciri-ciri larva Anopheles yang dapat diamati secara makroskopis yaitu tidak memiliki siphon tetapi memiliki palmate-hair yang khas bentuknya serta memiliki posisi mendatar saat berada di permukaan air. Sementara itu pengamatan secara mikroskopis dilakukan dengan cara pengamatan menggunakan mikroskop dan diidentifikasi dengan buku 'Kunci bergambar Jentik Anopheles di Indonesia Depkes RI 1999'.

Hasil identifikasi berdasarkan buku 'Kunci Bergambar Jentik Anopheles di Indonesia Depkes RI 1999' didapatkan hasil sebagai berikut: bulu clypeus dalam tidak berambut dan bulu kipas dengan daun yang panjang dan bulu kipas pada ruas abdomen I tidak sempurna, jarang dengan lembaran-lembaran yang bergerigi lebih dari 6 . Hasil penelitian ini mendapatkan bahwa spesies dari nyamuk Anopheles yang ditemukan di Kecamatan Sikakap Kabupaten Kepulauan Mentawai adalah Anopheles subpictus.

Uji Efektivitas Larvasida Bacillus thuringiensis israelensis

Untuk melakukan uji efektivitas Bacillus thuringiensis israelensis $\mathrm{H}-14$ terhadap larva nyamuk Anopheles subpictus yang ditemukan di Kecamatan Sikakap Kabupaten Kepulauan Mentawai, maka digunakan konsentrasi 0,0025, 0,005, 0,01, 0,02, dan $0,04 \%$. Dasar penggunaan konsentrasi ini adalah berdasarkan hasil penelitian pendahuluan, dimana pada konsentrasi $0,01 \%$ dapat mematikan larva lebih dari $50 \%$ dari jumlah larva setelah 48 jam perlakuan. Oleh karena itu, pada uji utama ditentukan 2 konsentrasi yang berada di bawah $0,01 \%$ yaitu 0,0025 dan $0,005 \%$ dan 2 konsentrasi diatasnya yaitu 0,02 dan $0,04 \%$. 
Tabel 1. Persentase kematian Larva Nyamuk Anopheles subpictus pada berbagai konsentrasi Bacillus thuringiensis israelensis $\mathrm{H}-14$ setelah 24 jam perlakuan.

\begin{tabular}{|c|c|c|c|c|c|}
\hline \multirow[t]{2}{*}{$\begin{array}{c}\text { Konsentrasi } \\
(\%)\end{array}$} & \multicolumn{3}{|c|}{$\begin{array}{l}\text { Jumlah kematian } \\
\text { larva setelah } 24 \\
\text { jam setelah } \\
\text { perlakuan pada } \\
\text { ulangan ke }\end{array}$} & \multirow[t]{2}{*}{$\begin{array}{c}\text { Rata- } \\
\text { rata } \\
\text { jumlah } \\
\text { kematia } \\
n \\
\text { (ekor) }\end{array}$} & \multirow[t]{2}{*}{$\begin{array}{c}\text { Persent } \\
\text { ase } \\
\text { kematia } \\
\text { n larva } \\
(\%)\end{array}$} \\
\hline & 1 & II & III & & \\
\hline 0 (kontrol) & 0 & 0 & 0 & 0 & 0 \\
\hline 0,0025 & 3 & 5 & 3 & 3,6 & 18 \\
\hline 0,005 & 7 & 9 & 10 & 8,6 & 43 \\
\hline 0,01 & 14 & 13 & 14 & 13,6 & 68 \\
\hline 0,02 & 17 & 15 & 17 & 16,3 & 81,5 \\
\hline 0,04 & 18 & 16 & 17 & 17 & 85 \\
\hline
\end{tabular}

Pada Tabel 1 diatas didapatkan bahwa pada kelompok perlakuan larvasida setelah 24 jam kematian terendah terdapat pada konsentrasi $0.0025 \%$ dengan persentase kematian larva sebesar $18 \%$, sedangkan kematian tertinggi terdapat pada konsentrasi $0.04 \%$ dengan persentase kematian larva sebesar $85 \%$.

Tabel 2. Persentase kematian Larva Nyamuk Anopheles subpictus pada berbagai konsentrasi Bacillus thuringiensis israelensis $\mathrm{H}-14$ setelah 48 jam perlakuan.

\begin{tabular}{|c|c|c|c|c|c|}
\hline \multirow[t]{2}{*}{$\begin{array}{c}\text { Konsentrasi } \\
(\%)\end{array}$} & \multicolumn{3}{|c|}{$\begin{array}{l}\text { Jumlah kematian } \\
\text { larva setelah } 48 \\
\text { jam setelah } \\
\text { perlakuan pada } \\
\text { ulangan ke } \\
\end{array}$} & \multirow[t]{2}{*}{$\begin{array}{c}\text { Rata- } \\
\text { rata } \\
\text { jumlah } \\
\text { kematia } \\
n \\
\text { (ekor) }\end{array}$} & \multirow[t]{2}{*}{$\begin{array}{c}\text { Persent } \\
\text { ase } \\
\text { kematia } \\
\text { n larva } \\
(\%)\end{array}$} \\
\hline & 1 & II & III & & \\
\hline 0 (kontrol) & 0 & 0 & 0 & 0 & 0 \\
\hline 0,0025 & 5 & 7 & 8 & 6,6 & 33 \\
\hline 0,005 & 12 & 14 & 13 & 13 & 65 \\
\hline 0,01 & 17 & 18 & 17 & 17,3 & 86,5 \\
\hline 0,02 & 19 & 18 & 20 & 19 & 95 \\
\hline 0,04 & 20 & 20 & 19 & 19,6 & 98 \\
\hline
\end{tabular}

Hasil uji pada kelompok perlakuan larvasida setelah 48 jam didapatkan kematian terendah terdapat pada konsentrasi $0.0025 \%$ dengan persentase kematian larva sebesar $33 \%$, sedangkan kematian tertinggi terdapat pada konsentrasi $0.04 \%$ dengan persentase kematian larva sebesar 98\%. Pada tabel tersebut dapat dilihat bahwa semakin besar konsentrasi semakin banyak larva yang mati.

Analisa Probit

Untuk penentuan efektivitas Bacillus thuringiensis israelensis digunakan analisa probit. Kematian larva nyamuk dengan nilai konsentrasi yang menyebabkan kematian $50 \%$ dan $90 \%$ dinyatakan dengan nilai LC50 dan LC90. Sedangkan waktu yang menghasilkan kematian larva $50 \%$ dan $90 \%$ dalam kondisi percobaan tertentu dinyatakan dengan nilai LT50 dan LT90.

Tabel 3. Analisa Probit Berdasarkan Waktu.

\begin{tabular}{ccc}
\hline $\begin{array}{c}\text { Waktu } \\
\text { (jam) }\end{array}$ & $\begin{array}{c}\text { LC } 50 \\
(\%)\end{array}$ & $\begin{array}{c}\text { LC } 90 \\
(\%)\end{array}$ \\
\hline 24 & 0.012 & 0.033 \\
48 & 0.005 & 0.016 \\
\hline
\end{tabular}

Hasil uji probit didapatkan bahwa setelah 24 jam perlakuan konsentrasi (LC50) yang dapat mematikan $50 \%$ larva adalah $0.012 \%$ dengan interval antara $0.010 \%$ dan $0.014 \%$. Sedangkan konsentrasi (LC90) yang dapat mematikan $90 \%$ larva adalah $0.033 \%$ dengan interval antara $0.029 \%$ dan $0.040 \%$.

Setelah 48 jam perlakuan, konsentrasi (LC50) yang dapat mematikan $50 \%$ larva adalah $0.005 \%$ dengan interval antara $0.004 \%$ dan $0.006 \%$. Sedangkan konsentrasi (LC90) yang dapat mematikan $90 \%$ larva adalah $0.015 \%$ dengan interval antara $0.013 \%$ dan $0.018 \%$.

Tabel 4. Analisa Probit Berdasarkan Konsentrasi

\begin{tabular}{ccc}
\hline $\begin{array}{c}\text { Konsentrasi } \\
(\%)\end{array}$ & $\begin{array}{c}\text { LT } 50 \\
\text { (menit) }\end{array}$ & $\begin{array}{c}\text { LT 90 } \\
\text { (menit) }\end{array}$ \\
\hline 0.0025 & 3256.34 & 4988.21 \\
0.005 & 2189.59 & 3496.79 \\
0.01 & 1576.67 & 2547.46 \\
0.02 & 1258.57 & 1981.88 \\
0.04 & 1123.30 & 1682.25 \\
\hline
\end{tabular}

Penghitungan menggunakan uji probit dengan konsentrasi $0.0025 \%$ didapatkan kematian larva $50 \%$ (LT50) dicapai pada menit ke 3256.34 dan kematian larva 90\% (LT90) akan dicapai pada menit ke 4988.21. Pada konsentrasi $0.005 \%$ didapatkan kematian larva $50 \%$ (LT50) dicapai pada menit ke 2189.59 dan kematian larva 90\% (LT90) akan dicapai pada menit ke 3496.79. Sedangkan pada konsentrasi $0.01 \%$ didapatkan kematian larva 50\% (LT50) dicapai pada menit ke 1576.67 dan kematian larva 90\% (LT90) akan dicapai pada menit ke 2547.46.

Penghitungan menggunakan uji probit dengan konsentrasi $0.02 \%$ didapatkan kematian larva $50 \%$ (LT50) dicapai pada menit ke 1258.57 dan kematian larva 90\% (LT90) akan dicapai pada menit ke 1981.88. Pada penghitungan dengan konsentrasi $0.04 \%$ didapatkan kematian larva 50\% (LT50) dicapai pada menit ke 1123.30 dan kematian larva 90\% (LT90) akan dicapai pada menit ke 1682.25. 


\section{PEMBAHASAN}

Identifikasi Larva Nyamuk Anopheles subpictus

Hasil penelitian ini mendapatkan bahwa spesies dari nyamuk Anopheles yang ditemukan di Kecamatan Sikakap Kabupaten Kepulauan Mentawai adalah Anopheles subpictus.

Berdasarkan tempat perindukan di daerah penelitian, maka yang didapatkan hanya Anopheles subpictus dan tidak ditemukan Anopheles sundaicus. Hal ini mungkin disebabkan karena waktu pengambilan sampel pada musim penghujan dan tempat perindukan yang dekat tepi pantai yang mempunyai kadar garam yang tinggi, sehingga hanya Anopheles subpictus yang ditemukan. Sementara nyamuk Anopheles sundaicus tumbuh optimal pada air payau yang memiliki kadar garam $12-18 \%$ dan tidak berkembang pada kadar garam $40 \%$ ke atas. ${ }^{1}$

Tempat perindukan Anopheles subpictus bervariasi, larva dapat hidup di air jernih maupun air keruh, di air tawar maupun air payau. Larva Anopheles subpictus sering ditemukan bersama dengan larva Anopheles sundaicus di lagun dan bersama Anopheles aconitus di persawahan. Di beberapa daerah pantai Bali Anopheles subpictus dan Anopheles sundaicus sering ditemukan di kolam ikan buatan. ${ }^{11}$ Di Sulawesi, walaupun sering terdapat bersama-sama, jumlah larva Anopheles subpictus selalu jauh lebih banyak daripada Anopheles sundaicus. ${ }^{12}$

Efektivitas Penggunaan Bacillus thuringiensis
israelensis

Hasil uji efektivitas menunjukkan persentase kematian 50\% larva instar III pada konsentrasi 0,005\% dan kematian larva $90 \%$ terdapat pada konsentrasi 0,015\% setelah 48 jam perlakuan. Menurut WHO, larvasida dikatakan efektif jika dapat membunuh larva sebesar $10-95 \%$ dari total larva uji. Pada penelitian ini didapatkan bahwa Bacillus thuringiensis israelensis $\mathrm{H}$ 14 efektif membunuh larva nyamuk tersebut pada nilai interval LC50 sebesar $0,004 \%-0,006 \%$ dan interval LC90 sebesar 0,013\%-0,018\%.

Penghitungan menggunakan uji probit dengan konsentrasi terendah yaitu $0,0025 \%$ didapatkan kematian larva 50\% (LT50) dicapai pada menit ke 3256,34 dan kematian larva 90\% (LT90) dicapai pada menit ke 4988,21. Pada penghitungan dengan konsentrasi tertinggi yaitu $0,04 \%$ didapatkan kematian larva 50\% (LT50) dicapai pada menit ke 1123,30 dan kematian larva 90\% (LT90) akan dicapai pada menit ke 1682,25 .

Bacillus thuringiensis merupakan racun perut bagi larva. Bacillus thuringiensis yang dimakan oleh larva akan larut di dalam usus larva, kemudian diubah menjadi toksin aktif oleh enzim proteolitik dalam usus larva dan akan berikatan dengan reseptor spesifik pada membran usus larva. Ikatan ini menyebabkan lisis epitel usus larva dan mengganggu permeabilitas cairan sehingga sel menjadi bengkak kemudian pecah dan mengakibatkan kematian larva. Toksin ini juga membuat penurunan nafsu makan pada larva, sehingga menyebabkan larva berhenti makan. ${ }^{13}$

Menurut WHO, keutamaan lain dari Bacillus thuringiensis israelensis adalah aman digunakan bagi lingkungan karena akan terurai oleh sinar ultraviolet, bersifat tidak toksik dan tidak patogen terhadap spesies bukan sasaran seperti cacing, ikan, burung, dan spesies lain yang hidup di dalam air. Bacillus thuringiensis israelensis yang kontak dengan kulit, mata, terhirup, termakan atau terminum tidak akan berbahaya pada kesehatan manusia. Dengan demikian larvasida Bacillus thuringiensis israelensis sangat direkomendasikan untuk digunakan dalam program pemberantasan vektor nyamuk Anopheles khususnya di daerah endemis malaria. ${ }^{14}$

Penelitian Achille et al menyatakan bahwa waktu pemaparan yang lama Bacillus thuringiensis dengan konsentrasi yang tinggi berpengaruh terhadap kematian larva. Daya bunuh Bacillus thuringiensis paling tinggi dalam waktu pemaparan 4 hari dan apabila lebih dari itu toksin yang dihasilkan bakteri akan mengendap di dasar tempat hidup larva. Waktu pemaparan yang lama atau lebih dari 4 hari akan menyebabkan efektivitas Bacillus thuringiensis menurun. Hal ini disebabkan karena ketersediaan nutrisi bakteri pada air menurun, maka populasi bateri juga menurun. ${ }^{15}$

Uji efikasi formulasi liquid (cair) Bacillus thuringiensis $\mathrm{H}-14$ galur lokal yang ditumbuhkan dalam media Tryptose Phosphate Broth (TPB) terhadap jentik Anopheles sundaicus di laboratorium dapat membunuh jentik pada dosis $0,0085 \mathrm{ml} / 100 \mathrm{ml}$ (LC50) dan 0,1000 $\mathrm{ml} / 100 \mathrm{ml}$ (LC90) selama 24 jam pengujian. Pada 48 jam pengujian membutuhkan dosis sebesar 0,0059 
$\mathrm{ml} / 100 \mathrm{ml}$ (LC50) dan 0,0751 ml/100 ml (LC90) untuk membunuh jentik Anopheles sundaicus. ${ }^{16}$

Penelitian ini tidak bisa menerangkan mekanisme dan jenis resistensi atau penurunan kerentanan yang terjadi terhadap nyamuk uji di Kecamatan Sikakap Kabupaten Kepulauan Mentawai, oleh karena itu dibutuhkan penelitian lebih lanjut untuk mengetahui jenis maupun mekanisme resistensi yang terjadi pada nyamuk uji.

\section{SIMPULAN}

Berdasarkan dari hasil penelitian mengenai penentuan spesies dan uji efektivitas Bacillus thuringiensis israelensis $\mathrm{H}-14$ terhadap larva nyamuk Anopheles spp sebagai vektor malaria di Kecamatan Sikakap Kabupaten Kepulauan Mentawai, dapat disimpulkan bahwa spesies Anopheles berdasarkan survei jentik yang ditemukan di Kecamatan Sikakap Kabupaten Kepulauan Mentawai adalah Anopheles subpictus. Larvasida Bacillus thuringiensis israelensis efektif membunuh larva Anopheles instar III dengan LC 50 sebesar 0,005 \% dan LC 90 sebesar 0,015\% setelah 48 jam perlakuan. Pada konsentrasi terendah yaitu $0,0025 \%$ didapatkan LT50 dicapai pada menit ke 3256,34 dan LT90 dicapai pada menit ke 4988,21. Pada konsentrasi tertinggi yaitu $0,04 \%$ didapatkan LT50 dicapai pada menit ke 1123,30 dan LT90 dicapai pada menit ke 1682,25.

\section{DAFTAR PUSTAKA}

1. Arsin AA. Malaria di Indonesia Tinjauan Aspek Epidemiologi. Makassar: Masagena Press; 2012; 25-136.

2. World Health Organization. World Malaria Report 2015. Geneva: WHO; 2016; 2-21.

3. World Health Organization. World Malaria Report 2016. Geneva: WHO; 2017; 2-26.

4. Kementerian Kesehatan Republik Indonesia. Data dan Informasi Profil Kesehatan Indonesia 2016. Jakarta: Kemenkes RI; 2017.

5. Dinas Kesehatan Provinsi Sumatera Barat. Profil Kesehatan Sumatera Barat 2016. Dinkes Sumbar; 2016; 85-88.

6. Soedarto. Malaria. Jakarta: Sagung Seto; 2011; 21-90.

7. Poopathi S, Abidha S. Mosquitocidal bacterial toxins (Bacillus sphaericus and Bacillus thuringiensis israelensis): Mode of action, cytopathological effects and mechanism of resistance. Journal of Physiology and Pathophysiology. 2011; Vol. 1 No.3; 22-38.

8. Dylo P, Martin C, Mhango C. Efficacy of Bacillus thuringiensis var israelinsis (Bti) on Culex and Anopheline mosquito larvae in Zomba. Malawi Journal of Science and Technology. 2014; Vol 10. No. $1 ; 40-52$.

9. Yusuf, Y. Penggunaan Bakteri Bacillus spp untuk Pengendalian Jentik Nyamuk Anopheles spp (Application of Bacillus spp as Microbial Larvicides to Control Anopheles Larvae). Bionature. 2009; Vol. 10 No. 2 ; $102-105$.

10. Charles JF, Delecluse A, Nielsen C. Entomopathogenic bacteria from laboratory to field applications. Berlin: Springer. 2000; 524.

11. Soekirno $M$, Bang $\mathrm{YH}$, Sudomo $M$, Pemayun $T$, Fleming GA. Bionomic of Anopheles sundaicus and other anophelines associated with malaria in coastal areas of Bali, Indonesia. WHO/VBC/83. 885. Geneva: WHO; 1983.

12. Collin SRT, Jung RK, Hasan A, Sutrsno RH, Pulut D. A Study of coastal malaria vectors Anopheles sundaicus and Anopheles subpictus Grassi in South Sulawesi, Indonesia. WHO/VBC/79.740; Geneva: WHO; 1979.

13. Nartey R, Dabo EO, Kruppa T, Awuah SB, Annan A, Oppong $S$, et al. Use of Bacillus thuringiensis var israelensis as a viable option in an Integrated Malaria Vector Control Programme in the Kumasi Metropolis, Ghana. BioMed Central. 2013; Vol. 16 No. 116; 1-10.

14. World Health Organization. Microbal pest control agent Bacillus thuringiensis. Geneva: WHO; 1999.

15. Achille GN, Christophe HS, Yilian L. Effect of Bacillus thuringiensis var. israelensis $\mathrm{H}-14$ on Culex, Aedes and Anopheles larvae. Benin: Journal of Stem Cell; 2010; Vol. 1 No. 1; 60-66.

16. Blondine, Damar, Widyastuti U. Pengendalian Vektor Malaria Anopheles Sundaicus Menggunakan Bacillus Thuringiensis 0-14 Galur Lokal yang Dibiakkan dalam Buah Kelapa dengan Partisipasi masyarakat di Kampung Laut Kabupaten Cilacap. Jurnal Ekologi Kesehatan; 2004; Vol. 3 No. 1; 24-36. 